\title{
'Historical Craft from the Artisan's Point of View'. Analysis of the Results of the Survey Conducted Among Craftsmen Specialising in Historical Reconstruction
}

\section{Introduction}

Objects displayed in museums are not always the original objects excavated by archaeologists. In some cases, when an artefact has not survived or is in a poor condition, its contemporary reconstruction is exhibited. Such objects, former everyday items, meticulously reconstructed and placed in museum display cabinets, rarely raise questions about the reconstruction accuracy in technological terms. Were they really made using ancient methods?

To archaeologists specialising in prehistory, material heritage is particularly important on account of scarce written and iconographic sources that can provide some information. In the case of the Przeworsk culture, we have abundant and diverse burial materials and, thanks to them, also data on the period. The information lost due to funeral rites involving burning the dead are compensated for by specialist analyses of the artefacts that allow archaeologists to recreate a relatively accurate image of the past.

Ethnographic research methods, such as ethnographic interviews, obviously cannot be employed in the case of the Przeworsk culture. However, it is possible to use these methods when studying issues concerning ancient crafts 
and to conduct ethnographic interviews with experienced folk artisans as long as one takes into account certain limitations connected with the specific character of the crafts produced in modern, or even contemporary, times. This can be easily illustrated with a blacksmith working in the $20^{\text {th }}$ century and producing mostly agricultural tools. The work of an analogous craftsman in the ancient times covered a much wider array of items including ornaments, other clothing elements, arms, and many other iron objects. The above comparison shows that studies based on the knowledge and skills of folk artisans cannot provide answers to all questions asked by researchers interested in ancient crafts. Considering the above, the best research results can be obtained by analysing the working methods of craftsmen who specialise in artefact reconstruction.

However, one should first decide when an artefact is a good reconstruction, and when it is only an item resembling or imitating the original visually. According to the assumptions of experimental archaeology, in order to perform an experiment leading to the creation of the expected reconstruction, one should meet certain requirements. Most of all, one has to use the same materials and methods that were available in the period in question, establish the goal of the experiment, and verify its results by reproducing them (Coles 1977; Ławrynowicz 2012). We decided to conduct our own survey and ask the artisans what they thought about their work and products.

\section{The Survey Goal, Scope and Methodology}

In this paper, we would like to present the results of the survey we conducted at the end of 2016 and at the beginning of 2017. It has to be noted that this was qualitative and not quantitative research as the number of respondents falling within our research interests does not exceed a few dozen people in Poland. We prepared a questionnaire for Polish artisans who deal with historical reconstruction and present their products at archaeological festivals to promote archaeology and history. The number of respondents is small due to a high level of professional knowledge and practical skills that are required to produce faithful copies of objects created in the antiquity. Such a combination is rarely acquired by one person. Twenty-four persons filled in our questionnaires, and four refused to take part in the survey ${ }^{\mathrm{I}}$.

I We would like to thank the twenty-four respondents who took part in the survey. Nineteen persons consented to the publication of their names. The respondent list: Krzysztof Dziewiętkowski, Monika Fik, Małgorzata Gławińska, Bartosz Głuszczak, Paulina Gorazd-Dziuban, Łukasz Kieferling, Damian Kołtuniak, Mateusz Kosiński, Bartosz Kowalski, Dagmara Łaciak, Michał Majcher, Kasia Małusza, Daniel Marciniak, Eryk Popkiewicz, Andrzej Przychodni, Łukasz Sajnóg, Łukasz Sędyka, Ewa Wojtyła, Adrian Wrona. 
In the group we analysed, there were at least thirteen archaeologists, which proves their specialist qualifications for the handicraft work they perform. A high proportion of the respondents have higher education (including three Doctors, two PhD students, at least eight Masters of Arts, and two students ${ }^{2}$ ). The survey participants practice different crafts. The group included three potters, four shoemakers/leather workers, six people dealing with metalwork ${ }^{3}$, seven specialising in textiles, and four dealing with other types of production.

The aim of those artisans is to reconstruct artefacts using technological methods and designs identical to those used in the past. In order to make our survey as reliable as possible, we limited its framework to the crafts from one historical period: antiquity ${ }^{4}$. In this simple way we are going to demonstrate the relationships between a small group of craftsmen who reconstruct antiquities and the academic world, and how important it is to acquire historical and archaeological knowledge and to find ethnographic inspirations in order to solve the problems of craft techniques.

The survey included I2 questions the aim of which was to obtain answers concerning difficulties and dilemmas artisans face when recreating artefacts.

\section{Survey Results}

1. What is the greatest problem when reconstructing an artefact? The greatest problem indicated in $46 \%$ of the answers is access to documentation and the artefact itself. Despite a large number of readily available publications, they do not always contain the basic information necessary to reconstruct an artefact. A frequent complication is the lack of a sufficient number of sections. In the case of pole weapon heads, merely two or three sections do not provide full information about changes in the artefact's geometry. Rough drawings raise more questions than they give answers. A solution, at least to some of these doubts, would be good photographic documentation in publications.

According to the respondents, direct contact with the artefact is sometimes difficult or even impossible on account of limited access to museum resources. The exhibits in display cabinets are usually arranged in a way showing only one side, while in order to reconstruct them, one needs to see them whole.

\footnotetext{
2 The question about education was not obligatory and not all respondents answered it.

3 This number includes persons who deal with smelting, smithery, and bronze work.

4 For the purpose of this article we use the term "antiquity" to describe the time of the Przeworsk culture.
} 
Another important problem indicated by our respondents is the obtaining of raw materials that are identical to the historical ones or at least have analogous properties. It is worth paying attention to this issue. Artisans reconstructing pottery do not encounter any problems with obtaining the right material. The clay we use today has the same properties as the clay extracted in the antiquity. The situation is completely different in the case of textiles as some sheep breeds popular in the antiquity are no longer bred or are bred to a very limited extent, and so access to their fleece is very poor. It is even more difficult for blacksmiths who want to practice their craft employing ancient methods. Their raw material should only be bloomery steel meaning iron smelted in a slag pit bloomery furnace. Today, only a small group of specialists use bloomeries for smelting. They do it for experimental or popularising purposes, and the iron they obtain is unique and difficult to come by.

A problem indicated less frequently is the lack of time the respondents can devote to crafts. In isolated cases, the largest challenge turns out to be the recreation of the whole process of creating the original object. When a replica is ordered, there are sometimes problems with coming to an agreement with the ordering party.

2. How do people respond to what you do? With this question, we wanted to learn how the crafts employing ancient methods are perceived by people who are not directly connected with the academic circles. Twenty-two respondents received positive feedback, and sometimes even admiration. This does not mean, however, that the respondents have never encountered any negative responses. Some of them reported bewilderment or even aversion. This is well illustrated by a fragment of one of the answers: '[People's responses are] rather positive but one of the boys I dated said that I had to be immature to be dealing with reconstruction. This was our last meeting. According to the respondents, positive and negative responses depend on the person and not on what they do or how they do it.

3. Are you in contact with the academic circles? This question concerned the surveyed artisans' contacts with the academic circles of archaeologists exploring the issue of ancient crafts. As many as thirteen people openly stated that they had archaeological education, conducted scientific experiments on their own, and publish their results. This shows that in order to practise crafts employing the techniques used in the reconstructed period one needs highly specialist knowledge, the exchange of conclusions and observations with other specialists, and the performance of one's own experiments.

Let us sum up this question with a quote from one of the artisans: 'Of course.

I cooperate with both museums and archaeologists. However, I receive the 
greatest support from archaeology students, to whom sharing their knowledge is as obvious as breathing. Cooperation with conservative scientists is a bit more difficult as they do not take my activities connected with experimental archaeology seriously'.

4. What do scientists (e.g. archaeologists) think about your products? We established that all respondents had contacts with scientists. But what does the scientific world think about their activity and products? Once again, most respondents (I5) said they were received in a positive way, just like the author of the following words: 'The scientists I work with appreciate my products and their cognitive value connected with the educational possibilities offered by the presentation of the replica or the reconstruction of the production processes'.

However, there were also some negative experiences described: 'Some people treat it as popularising activity, but others see it as something frivolous or believe that copying archaeological artefacts is a violation of the copyrights of the artefact's owner'.

5. Which circles are most interested in your products? Which circles are most interested in reconstruction? Most respondents indicated historical reenactment groups. They also mentioned museums, archaeologists, and educational institutions. Some respondents indicated their friends or people interested in handicrafts.

This is how one of the artisans surveyed described his experiences: 'These are mostly people connected with ancient reenactment and archaeologists. This is perhaps because they are more aware of the effort it requires to prepare an accurate reconstruction'.

6. Where do you get information about the production technology from?,

7. What are your sources of historicallarchaeological knowledge? and

8. Do you derive inspiration from ethnographic research?

The most important element of artefact reconstruction is proper technical knowledge. In many cases this involves looking for guidelines and techniques related to the crafts the artisans practise. Fifteen respondents mentioned academic papers and historical sources as their basic and necessary starting point for acquiring technical knowledge. However, it has to be emphasised that all respondents gave more than one source of information, with many answers indicating the Internet as the basic source. In their answers to this question, the respondents frequently referred to specialist papers published online, praising easy access to them. A few respondents also emphasised the significance of sharing experiences with other artisans and how the method of trial and error helped them develop their skills. Fewer answers indicated historical material 
analysis. The artisans noted that, with certain knowledge of the production technology, you can resolve many doubts surrounding the creation of the artefact when you see it. A considerable proportion of the respondents dealing with practical aspects of ancient crafts are people who studied archaeology. Thus, their knowledge is based on the information they obtained as students, and in some cases also on the experience gained during field research which they took part in or conducted. The smallest group of the respondents treat ethnographic knowledge as a potential source of information.

As many as sixteen of the respondents confirmed that they supported their activity with ethnographic analogies. Seven artisans used them but not very often. It is worth emphasising that in their struggles with crafts all respondents used this source of knowledge at least once. At the same time, it has to be noted that in the case of some of the crafts, ethnography is the basic, and sometimes the only, source.

9. Do you use raw materials that are one-hundred percent historically accurate? According to the survey, one of the greatest problems encountered by artisans today is the use of one-hundred percent historically accurate raw materials. A large number of artisans try to use raw materials obtained or produced in the same way as in the antiquity. In the case of crafts for which it is not difficult to obtain raw materials, this is the standard procedure. In other cases, a difficult barrier to overcome is the price of raw materials, which is why the artisans are forced to use cheaper, contemporary substitutes. Thus, a basic distinction between an artefact reconstruction and a product that looks exactly like the original has to be made. This distinction is made clear by one of the answers: 'If the reconstruction is made for scientific purposes, then yes. But if the product is commercial, then it only needs to imitate the artefact visually'. What also needs to be considered is the fact that the use of one-hundred percent historically accurate raw materials may simply not be technically viable.

10. Do you employ production techniques that are one-hundred percent historically accurate? Reproducing ancient production techniques seems to be much easier and cheaper than using historical raw materials. Nearly a half of the artisans surveyed already use the same tools and techniques as in the antiquity, and many of the others are aiming to follow such practice, which is connected with the market demand. The use of contemporary power tools speeds up the work considerably. The visual difference in such cases is sometimes difficult to notice, which is why some of the artisans employ historical production techniques only in reconstructions undertaken for experimental (and scientific) purposes or to their own satisfaction. It is worth 
quoting here the words of one of our respondents: 'When I want to verify the usefulness or effectiveness of a tool, then I use its replica, however, it takes much time, so I don't do it in the case of commercial products'.

Foreign artisans have a similar attitude towards reconstruction. A useful analogy is that of the work on recreating the Huldremose skirt, described by Anna Nørgaard, a professional weaver, who meticulously selected materials and planned the production technique before she started weaving. In the process, she mostly considered the ultimate application of her work: whether the skirt was made for educational purposes, whether it would be touched or only watched, and how much the reconstruction could cost (Nørgaard 2008).

11. Why do you reconstruct artefacts, what is your purpose? Why are objects from different periods reconstructed? To nearly a half of the artisans, the motivation is the cultivation of their interests. However, this is not the only reason why they specialise in reconstruction. The respondents are also driven by the satisfaction derived from this kind of work and by material gain. Another recurring answer was given by the respondents who believed that their craft was closely related to archaeology. Sometimes, the only way to get to know the technique for the production of historical objects is to verify it through experimental archaeology. To many of the respondents, artefact reconstruction is thus a significant contribution to science, which also allows to popularise history and archaeology.

12. What other problems do you encounter when you reproduce artefacts? The last question was supposed to supplement the previous answers, offering a chance to reveal problems that were not directly linked to the subjects of the earlier questions. Most respondents, however, once again talked about the issues causing them most troubles. The most important of them was incomplete documentation lacking information that would allow them to reproduce the item. In extreme cases, only careful, direct observation of the artefact makes it possible to accurately reproduce its appearance. Unfortunately, museums never display some of their most valuable artefacts, which creates another barrier to artisans. Poor condition of artefacts further limits the possibility of interpretation.

To most artisans, the crafts are only an additional source of income or even a hobby. In the contemporary society, the interest in the reproduction of antiquities is still too small for even the finest artisans to be able to earn their living this way. The necessity to find a different job naturally entails problems with finding sufficient amount of time that is necessary to practise a craft as a profession. 
Another problem specialist artisans are faced with is ecology as it does not always go hand in hand with experimental archaeology. Protected plant and animal species often constitute a significant problem for artefact reconstruction. Some of the objects created in the antiquity were made of raw materials acquired from plants and animals that are now protected. In order to produce such artefacts it is necessary to find substitutes or use completely different materials. A good example is the gladius (sword) found in a Danish bog in Illerup Ådal, which has an ivory hilt (Ilkjaer 2007: 80).

\section{Conclusions}

Analysis of the above answers leads to both positive and negative conclusions. We would like to start with the latter. The fundamental problem connected with artefact reconstruction is the lack of sufficiently detailed archaeological documentation and limited access to originals, which translates into a limited possibility of closely examining the object. This proves the crucial role of specialist analyses and accurate drawing and photographic documentation allowing to determine the dimensions, weight, material, and many other characteristics of the artefact to be reproduced. The results of the artisan's work depend to a large extent on the above information (or its lack).

An alternative or a supplement to printed documentation can be direct observation of the artefact in the museum. Unfortunately, in many cases the way exhibits are displayed does not match the artisan's expectations and does not allow any close examination.

The perception of the crafts and their products is not always positive. The reason for this may be a lack of understanding for the reconstruction itself or insufficient specialist historical knowledge among the recipients. Potential sources of such knowledge are archaeological festivals organised more and more often in the whole Poland, the scientific value of which increases each year thanks to the involvement of people who have archaeological background. The events mentioned combine popularisation with displays of experimental archaeology prepared by entities cooperating with research institutions.

Our respondents also noted that the greatest sceptics about historical reconstruction are researchers who encountered it only at the beginning of its way, when it was on a relatively low level. Today, a large proportion of people dealing with experimental archaeology are representatives of the young generation of archaeologists, who readily base their research on the experience 
of artisans specialising in their issues of interest. Thus established cooperation between scientists and artisans is founded on mutual trust, which results from the high level of the artisans' knowledge they derive from their own experience and from academic publications. Moreover, many people dealing with artefact reconstruction strive for perfection in their jobs, and they are frequently inspired by ethnographic analogies. The multitude of sources of knowledge and experiences ensures very high quality of the final product. Thanks to this, it is getting easier and easier for qualified artisans to establish cooperation with museums and educational institutions interested in their work.

A phenomenon worth emphasising is the growing number of archaeologists who explore the technological aspects of artefact analysis through artefact reconstruction. This entails a completely new perspective on the material heritage that is carefully studied by scientists. It should be noted that the interest in experimental archaeology is not limited to antiquity, but it is also practised in connection with other periods, mostly Early Middle Ages. Even museum branches are established, such as Żmijowiska Hillfort - a branch of the Museum on the Vistula in Kazimierz Dolny, or Grzybowo Hillfort, which is an entity managed by the Museum of the First Piasts at Lednica, the activity of which focuses on experiments and the popularisation of knowledge of the past (Archeologia doświadczalna w Muzeum Nadwiślańskim... 2007; Łukaszyk 20I2).

To conclude, based on the results of the survey we conducted it can be said that the quality of the reconstructions produced in Poland is constantly growing, which translates into the growing understanding of the problems encountered by contemporary artisans in their work. This is an optimistic prognosis for the development of future research into the production technologies of the past.

We decided to end with a quote from one of the respondents who well answers the problem raised in the title of our paper: when an artefact is reconstructed, and when a product only resembles an item from a different period:

I believe that for an object to be called an artefact reproduction, the following criteria have to be met: it has to be made with the same raw materials as the original; the raw materials need to be obtained/produced in the same way as in the period the artefact comes from; it has to be made with tools and raw materials used in a given period, employing the same technique/technology; and it has to be fully functional, which means that it has to have the same properties and serve the same purpose as the original. If an object fails to satisfy the above criteria, then it should not be called a reconstruction. 


\section{Bibliography}

Archeologia doświadczalna w Muzeum Nadwiślańskim. Eksperymenty 2003-2006

(2007), P. Lis (ed.), Muzeum Nadwiślańskie, Kazimierz Dolny.

Coles J. (1977), Archeologia doświadczalna, PWN, Warszawa.

Ilkjaer J. (2007), Illerup Ådal. Czarodziejskie zwierciadto archeologii, Wydawnictwo Trio, Warszawa.

Ławrynowicz O. (2012), Wspótczesne rekonstrukcje uzbrojenia średniowiecznego. Jeszcze amatorstwo czy już archeologia doświadczalna?, [in:] J. Gancarski (ed.), Skanseny archeologiczne i archeologia eksperymentalna, Muzeum Podkarpackie, Krosno, p. 631-644.

Łukaszyk A. (2012), Archeologia eksperymentalna - teoria, praktyka i doświadczenie, "Studia Lednickie", 11, p. 123-131.

Nørgaard A. (2008), A Weaver's Voice: Making Reconstructions of Danish Iron Age

Textiles, [in:] M. Gleba, C. Munkholt, M.L. Nosch (ed.), Dressing the Past, Oxbow, Oxford (Ancient Textiles Series, 3), p. 43-58.

\section{Summary}

'Historical Craft from the Artisan's Point of View'. Analysis of the Results of the Survey Conducted Among Craftsmen Specialising in Historical Reconstruction

The paper presents the results of the survey carried out by the authors of this paper, the subject of which was experimental archaeology. We asked a group of artisans that deal with historical reconstruction a set of questions about the difficulties they encounter during their reconstruction work. What is their biggest problem? Where do the craftsmen derive information about the ancient technology from? How are their products received by recipients? The chronological framework of the reconstruction industry was narrowed down to one historical period (the time of the Przeworsk culture, that is the Pre-Roman Iron Age, the Roman Iron Age and Migration Period). This clearly showed some connections between a small group of craftsmen using ancient methods in their work and the academic world, and how important it is to acquire historical and archaeological knowledge and to find ethnographic inspirations in order to solve the problems of craft techniques. The survey covered artisans practising various crafts, from metalwork to pottery, which added a broader perspective to the issues studied.

Keywords: experimental archaeology, artisan, artefact reconstruction 


\section{Streszczenie}

\section{"Rzemiosło historyczne okiem wytwórcy". Analiza wyników badań ankietowych przeprowadzonych wśród rzemieślników specjalizujących się w odtwarzaniu zabytków starożytnych}

Artykuł przedstawia wyniki ankiet przeprowadzonych przez autorów, których przedmiotem była archeologia eksperymentalna. Do grupy rzemieślników zajmujących się rekonstrukcją skierowano pytania dotyczące trudności, z którymi spotykają się podczas swojej pracy odtwórczej. Co jest największym problemem? Skąd rzemieślnicy czerpią informacje dotyczące technologii wytwórstwa? Jak ich wyroby są przyjmowane przez odbiorców? Ramy chronologiczne odtwórstwa zawężono do jednego okresu historycznego (czasu występowania kultury przeworskiej, a więc okresu przedrzymskiego, okresu wpływów rzymskich i okresu wędrówek ludów). Pozwoli to uczytelnić powiązania między niewielką grupą rzemieślników zajmujących się rękodzielnictwem metodami starożytnymi a światem naukowym, zdobywaniem wiedzy historycznej i archeologicznej oraz inspiracji etnograficznych w celu rozwiązania problemów technik rzemieślniczych. Badaniami zostały objęte osoby zajmujące się różnymi rzemiosłami, od obróbki metalu po garncarstwo, co pozwala spojrzeć na owo zagadnienie z szerszej perspektywy.

Słowa kluczowe: archeologia eksperymentalna, rzemieślnik, rekonstrukcja zabytku

Katarzyna Badowska, PhD student

University of Łódź, Institute of Archaeology

e-mail: k.m.badowska@gmail.com

Wojciech Rutkowski, PhD student

University of Łódź, Institute of Archaeology

e-mail: w.rutkow92@gmail.com 